Short communication

\title{
Crotalus durissus sp. rattlesnake venom induces toxic injury in mouse sperm
}

\author{
Fábio Henrique Fernandes ${ }^{\mathrm{a}, *}$, Eduardo Bustos-Obregon ${ }^{\mathrm{b}}$, Rosemary Matias ${ }^{\mathrm{c}}$, \\ Doroty Mesquita Dourado ${ }^{\mathrm{d}}$ \\ a São Paulo State University - UNESP, Medical School, Department of Pathology, Rubião Junior, 18618-000, Botucatu, São Paulo, Brazil \\ ${ }^{\mathrm{b}}$ University of Chile, Medical School, Av. Independencia 1027, Santiago, Chile \\ ${ }^{\mathrm{c}}$ Anhanguera-Uniderp University, Environment and Regional Development, Postgraduate Program, R. Alexandre Herculano, 1400, 79037-280, Campo Grande, Mato \\ Grosso do Sul, Brazil \\ ${ }^{\mathrm{d}}$ Anhanguera-Uniderp University, Laboratory of Toxinology and Medicinal Plants, R. Alexandre Herculano, 1400, 79037-280. Campo Grande, Mato Grosso do Sul, Brazil
}

\section{A R T I C L E I N F O}

\section{Keywords:}

Snakebites

Germ cells

Chromatin condensation

\begin{abstract}
A B S T R A C T
Accidents involving snakebites constitute a serious public health problem in many regions around the world. However, there are no study about a possible action of snake venom on the reproductive system. Herein we show that Crotalus durissus sp. (Linnaeus) rattlesnake venom $(25 \mu \mathrm{g} / \mathrm{kg}$ of body weight) affected chromatin condensation, and increased the number of sperm with abnormal morphology and the sperm count. In conclusion, besides the known hazards of the $C$. durissus sp. venom to animal health, this study was the first to show its effect also on male germ cells.
\end{abstract}

Accidents involving snakebites constitute a serious public health problem in many regions around the world (Kasturiratne et al., 2008). According to the World Health Organization (WHO), around 81,000 to 138,000 people die each year as a result of snake bites, and around three times as many amputations and other permanent disabilities are caused by snakebites annually (WHO, 2018). In Brazil, among registered snake bites, those by Crotalus are responsible for the highest mortality rate (Frezzatti and Silveira, 2011). Several studies have demonstrated the hazards of the snakebites on human health (Gutiérrez et al., 2017). Damage to the nervous system (Del Brutto and Del Brutto, 2012), muscles (Mebs and Ownby, 1990), and acute renal failure (Pinho et al., 2005) have been reported. However, as far as we kwon, there are no study about a possible action of snake venom on the reproductive system of the people who were bitten. Thus, the effect of Crotalus durissus sp. (Linnaeus) venous on mouse spermatozoa was investigated. The protocol (Protocol 034) used in this study was approved by the Bioethics Committee of the University for the Development of the State and the Pantanal Region (UNIDERP).

Crotalus durissus sp. venom was obtained from the serpentarium of the UNIDERP (Campo Grande, Mato Grosso do Sul State, Brazil). A dehydrated venom sample was weighed and dissolved in saline solution $(0.9 \% \mathrm{NaCl})$, immediately before use in the experiments. Three-monthold and sexually mature male CF- 1 mice (38-41 g) were obtained from the animal facilities of the University of Chile and maintained in a room under controlled conditions of temperature $\left(22 \pm 2{ }^{\circ} \mathrm{C}\right)$ and a $12 \mathrm{~h}$ light/dark cycle, with ad libitum access to commercial diet and tap water. Then, the animals were distributed into two groups $(n=6 /$ each): 1- Negative control - which was treated only with the saline solution; 2 - Venom group, that received the Crotalus durissus sp. venom ( $25 \mu \mathrm{g} / \mathrm{kg}$ body weight - bw). Both saline and venom were injected via gastrocnemius muscle, in order to simulate the snakebite. Venom dose used corresponded to the intramuscular lethal dose 50 (LD50) of the Crotalus durissus terrificus venom in mice $(0.56 \mathrm{mg} / \mathrm{kg})$, as cited by Ribeiro et al. (1993). Four days after treatments, animals were killed (intraperitoneal injection of ketamine $-44 \mathrm{mg} / \mathrm{kg} / \mathrm{bw}$ ip.), and sperm cells collected from the cauda epididymis (Fornés and Bustos-Obregón, 1994). Sperm morphology and chromatin condensation were analyzed using the protocol described by Vigil and Bustos-Obregon (1985) and by Fornés and Bustos-Obregón (1994), respectively. DNA integrity was evaluated using the fluorescence acridine orange test (Tejada et al., 1984). Statistical analysis was performed using the Mann-Whitney test.

The data showed that Crotalus durrisus sp. venom affected chromatin condensation (decreased the ability of condensation), and increased the number of sperm with abnormal morphology (Fig. 1) and the sperm count (Table 1). No effect was detected on DNA integrity (Table 1).

According to Tasoulis and Isbister (2017), the main component in

\footnotetext{
* Corresponding author. Department of Pathology, UNESP/Botucatu Medical School, São Paulo State University, Rubião Júnior, 18.618-687, Botucatu, São Paulo, Brazil.

E-mail addresses: fernandesfh@gmail.com (F.H. Fernandes), ebustos@med.uchile.cl (E. Bustos-Obregon), rosematiasc@gmail.com (R. Matias), douradod@uol.com.br (D.M. Dourado).
} 
Sperm chromatin condensation

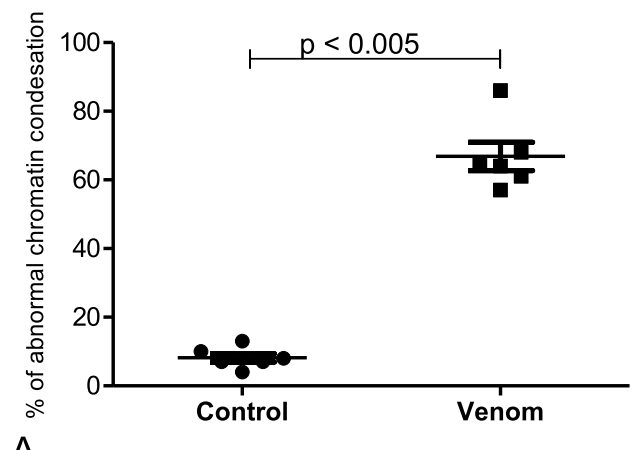

A

\section{Sperm morphology}

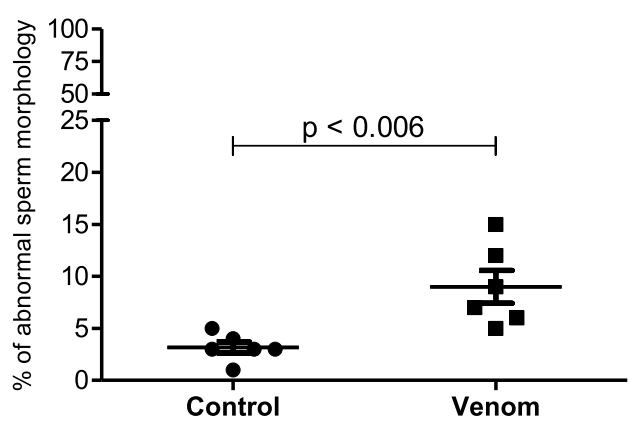

B

Fig. 1. Percentage of sperm with abnormal condensed chromatin (A) and morphology (B) in mice treated with Crotalus durissus sp. venom (25 $\mu \mathrm{g} / \mathrm{kg}$ body weight). Mean \pm SEM.

Table 1

Sperm count and DNA integrity in mice treated with a single dose of Crotalus durissus sp. venom $(25 \mu \mathrm{g} / \mathrm{kg}$ body weight).

\begin{tabular}{lll}
\hline Endpoints/Groups & Control $^{\mathrm{a}}$ & Venom \\
\hline Sperm count $\left(10^{6}\right.$ sperm/g) & $47.3 \pm 13.9$ & $102.6 \pm 56.1^{*}$ \\
Normal sperm DNA integrity (\%) & $98.5 \pm 1.0$ & $97.1 \pm 2.8$ \\
\hline
\end{tabular}

a $0.9 \% \mathrm{NaCl}$; mean $\pm \mathrm{SD} ;{ }^{*} \mathrm{p}<0.05$.

the venom of Crotalus durissus sp. is the phospholipase $\mathrm{A}_{2}\left(\mathrm{PLA}_{2}\right)$. Studies have shown that this ophidic enzyme induces damage in membrane of goat (Rahmy and Ayoub, 2002) and mouse spermatozoa (Escoffier et al., 2010). Therefore, it is plausible to suggest the increase of sperm with abnormal morphology could have been mediated by the PLA $_{2}$. Similarly, the modification of the sperm chromatin condensation could be due to phosphodiesterases, since these enzymes are able to degrade the H2B histones (Gronow and Chapleo, 1979). Data obtained by Georgieva et al. (2010) confirm the presence of this class of enzymes in the venom of the South American rattlesnakes (Crotalus durissus terrificus).

Regarding the increased number of sperm in the cauda epididymis of those mice treated with the venom, it is difficult to explain. Perhaps, some venom toxin could have stimulated spermiation or sperm disengagement (instantaneous event when sperm are rapidly swept away from the spermiation site to make their way to epididymis), favoring the sperm released by contractions of the peritubular myoid cells surrounding the seminiferous tubules (O'Donnell, 2014; O'Donnell et al., 2011).

In conclusion, besides the known hazards of the Crotalus durissus sp. venom to animal health, this study was the first to show its effect also on male reproductive cells.

\section{Transparency document}

Transparency document related to this article can be found online at https://doi.org/10.1016/j.toxicon.2018.08.006.

\section{References}

Del Brutto, O.H., Del Brutto, V.J., 2012. Neurological complications of venomous snake bites: a review. Acta Neurol. Scand. 125, 363-372. https://doi.org/10.1111/j.16000404.2011.01593.x.
Escoffier, J., Couvet, M., de Pomyers, H., Ray, P.F., Sève, M., Lambeau, G., De Waard, M., Arnoult, C., 2010. Snake venoms as a source of compounds modulating sperm physiology: secreted phospholipases $\mathrm{A}_{2}$ from Oxyuranus scutellatus scutellatus impact sperm motility, acrosome reaction and in vitro fertilization in mice. Biochimie 92, 826-836. https://doi.org/10.1016/j.biochi.2010.03.003.

Fornés, M.W., Bustos-Obregón, E., 1994. Study of nuclear decondensation of the rat spermatozoa by reducing agents during epididymal transit. Andrologia 26, 87-92. https://doi.org/10.1111/j.1439-0272.1994.tb00763.x.

Frezzatti, R., Silveira, P.F., 2011. Allopurinol reduces the lethality associated with acute renal failure induced by Crotalus durissus terrificus snake venom: comparison with probenecid. PLoS Neglected Trop. Dis. 5, e1312. https://doi.org/10.1371/journal. pntd.0001312.

Georgieva, D., Öhler, M., Seifert, J., Bergen, M. von, Arni, R.K., Genov, N., Betzel, C., 2010. Snake venomic of Crotalus durissus terrificus - correlation with pharmacological activities. J. Proteome Res. 9, 2302-2316. https://doi.org/10.1021/pr901042p.

Gronow, M., Chapleo, M.R., 1979. Presence of a histone H2B protease in snake venom phosphodiesterase. FEBS Lett. 103, 352-354.

Gutiérrez, J.M., Calvete, J.J., Habib, A.G., Harrison, R.A., Williams, D.J., Warrell, D.A., 2017. Snakebite envenoming. Nat. Rev. Dis. Primers 3, 17063. https://doi.org/10. 1038/nrdp.2017.63.

Kasturiratne, A., Wickremasinghe, A.R., de Silva, N., Gunawardena, N.K., Pathmeswaran, A., Premaratna, R., Savioli, L., Lalloo, D.G., de Silva, H.J., 2008. The global burden of snakebite: a literature analysis and modelling based on regional estimates of envenoming and deaths. PLoS Med. 5, e218. https://doi.org/10.1371/journal.pmed. 0050218.

Mebs, D., Ownby, C.L., 1990. Myotoxic components of snake venoms: their biochemical and biological activities. Pharmacol. Ther. 48, 223-236.

O'Donnell, L., 2014. Mechanisms of spermiogenesis and spermiation and how they are disturbed. Spermatogenesis 4, e979623. https://doi.org/10.4161/21565562.2014. 979623.

O'Donnell, L., Nicholls, P.K., O'Bryan, M.K., McLachlan, R.I., Stanton, P.G., 2011. Spermiation: the process of sperm release. Spermatogenesis 1, 14-35. https://doi. org/10.4161/spmg.1.1.14525.

Pinho, F.M.O., Zanetta, D.M.T., Burdmann, E.A., 2005. Acute renal failure after Crotalus durissus snakebite: a prospective survey on 100 patients. Kidney Int. 67, 659-667. https://doi.org/10.1111/j.1523-1755.2005.67122.x.

Rahmy, T.R., Ayoub, M.A., 2002. In vitro action of cobra venom on goat spermatozoa ultrastructure by transmission and scanning electron microscopy. J. Venom. Anim. Toxins 8, 127-159. https://doi.org/10.1590/S0104-79302002000100011.

Ribeiro, L.A., Agostini-Utescher, C.L., Vieira, S.L.P., Fensterseifer, S., Mukuno, H., Jorge, M.T., 1993. Avaliação em camundongo da eficácia do antiveneno administrado no local da inoculação intramuscular do veneno de Crotalus durissus terrificus. J. São Paulo Inst. Trop. Med. 35, 23-27.

Tasoulis, T., Isbister, G.K., 2017. A review and database of snake venom proteomes. Toxins (Basel) 9, 2-23. https://doi.org/10.3390/toxins9090290.

Tejada, R.I., Mitchell, J.C., Norman, A., Marik, J.J., Friedman, S., 1984. A test for the practical evaluation of male fertility by acridine orange (AO) fluorescence. Fertil. Steril. 42, 87-91.

Vigil, P., Bustos-Obregon, E., 1985. Alkylating agents and mouse spermatogenesis: effects of a single dose of cyclophosphamide. Andrologia 17, 276-282. https://doi.org/10. 1111/j.1439-0272.1985.tb01002.x.

WHO - World Health Organization, 2018. Snakebite envenoming. http://www.who.int/ news-room/fact-sheets/detail/snakebite-envenoming, Accessed date: 10 August 2018. 